\title{
Psychological impact of the COVID-19 pandemic: Negative and positive effects in Spanish population during the mandatory national quarantine
}

\author{
Bonifacio Sandín, Rosa M. Valiente, Julia García-Escalera, Daniel M. Campagne and Paloma Chorot
}

Universidad Nacional de Educación a Distancia, Madrid, Spain

\begin{abstract}
The COVID-19 pandemic has been spreading rapidly in Spain. The objective of this work was to examine the psychological impact of the pandemic and the Spanish national quarantine that took place during March and April 2020. We investigated the prevalence of fear of coronavirus, emotional symptoms and sleep problems. We also examined possible positive effects. A sample of 1,161 participants (aged 19 to 84 years) completed online the Coronavirus Psychological Impact Questionnaire, the Intolerance of Uncertainty Scale-12, and the Positive and Negative Affect Schedule. Results indicated that the most common fears pertain to the domains of contagion/disease/death, social isolation, and employment/income issues. We found high levels of emotional impact reflected in fear of coronavirus, sleep problems, and emotional symptoms (preoccupation, distress, hopelessness, depression, anxiety, nervousness, and restlessness). Regression analyses revealed that intolerance of uncertainty and social media exposure are strong predictors of the impact. We also found some effects of the COVID-19 lockdown favoring positive personal experiences. A new self-report instrument to assess psychological impact of coronavirus is provided.
\end{abstract}

Keywords: COVID-19; coronavirus; anxiety; depression; distress; sleep problems; intolerance of uncertainty; media exposure; positive effects.

Impacto psicológico de la pandemia de COVID-19: Efectos negativos y positivos en población española asociados al periodo de confinamiento nacional

Resumen: La pandemia COVID-19 se ha extendido rápidamente en España. El objetivo del estudio fue examinar el impacto psicológico de la pandemia y el confinamiento nacional vivido en España durante los meses de marzo y abril de 2020. Se investigó la prevalencia del miedo al coronavirus, los síntomas emocionales, y los problemas de sueño. También examinamos los posibles efectos positivos. Una muestra de 1.161 participantes (edad: 19-84 años) cumplimentó online el Cuestionario de Impacto Psicológico del Coronavirus, la Escala de Intolerancia a la Incertidumbre -12, y las escalas PANAS de afecto positivo y negativo. Los resultados indican que los miedos más comunes corresponden a las categorías de contagio/enfermedad/muerte, aislamiento social, y problemas de trabajo/ingresos. Encontramos niveles elevados de impacto emocional reflejado en los miedos al coronavirus, problemas de sueño, y síntomas emocionales (preocupación, estrés, desesperanza, depresión, ansiedad, nerviosismo, e inquietud). La intolerancia a la incertidumbre y la exposición a los medios de comunicación son poderosos predictores del impacto. También encontramos que el confinamiento favorecía algunas experiencias personales positivas. Se indican algunas sugerencias para la intervención psicológica. Se aporta un nuevo instrumento de autoinforme para la evaluación del impacto psicológico del coronavirus.

Palabras clave: COVID-19; coronavirus; ansiedad; depresión; distrés; problemas de sueño; intolerancia a la incertidumbre; medios de comunicación; efectos positivos.

Received: April 25, 2020; accepted April 27, 2020.

Correspondence: Bonifacio Sandín, Facultad de Psicología, Juan del

Rosal 10, 28040 Madrid, Spain. bsandin@psi.uned.es 


\section{Introduction}

At the end of December 2019, in Wuhan (in the Chinese province of Hubei), a cluster of pneumonia cases of unknown etiology was reported, mostly vendors and distributors in the seafood market of Huanan. The World Health Organization (WHO) characterized the etiological agent as a new coronavirus, named as novel coronavirus 2019 (2019-nCoV), also SARS-CoV-2 (coronavirus-2 of severe acute respiratory syndrome). On January 11, 2020 China announced the first death related to the new coronavirus. In a few weeks the infection extended over China and other parts of the world in such a way that the WHO was obliged to declare (January 30) the disease «public health emergency of international importance».

On February 11, 2020, the WHO named this new coronavirus disease COVID-19 (coronavirus disease 2019). The disease extended over the entire world at unprecedented speed, and on March 11 the WHO declared it global pandemic as it affected more than 100 countries, with more than 100.000 cases infected by this new coronavirus.

Although properly said the denomination of the virus is SARSCoV-2 or 2019-nCoV, in several contexts the virus generally is identified with the name of the disease (for instance, as COVID-19). Although as yet there is no evidence, it was suggested that the disease caused by this virus is zoonotic by origin (that is, was infected through a host animal).

The first cases of COVID-19 in Europe appeared in France (January 24), Germany (January 25) and Italy (January 30; main infection focus in Europe). On January 31 the first cases in other European countries were reported, including Spain, Sweden, the United Kingdom ( 2 cases) and Russia (two cases). On March 26 the number of those infected in the world had already reached half a million, doubling in a few days (April 2) (Wikipedia, 2020a). When in Spain the first death of COVID-19 in Valencia was reported (March 4) there were already approximately 200 cases distributed over 15 Communities. The Spanish government decreed the state of alarm on March 14, on which date approximately 6000 cases and 200 deaths had been reported. From that moment and until the end of April, the numbers rose to 214.226 infected persons and 24.415 deaths (Wikipedia, 2020a,b).

The state of alarm was decreed by the government for the entire national territory in order to slow the expansion of the coronavirus and reduce the sanitary emergency that at that moment was growing in our country (BOE, 2020). Associated with the alarm state, the Spanish government imposed a state of confinement (lockdown), initially from March 14 to May 3, 2020, obligatory for the entire Spanish territory (a global quarantine in the whole territory). This confinement implied conditions of social distancing, home confinement, drastic limits on the freedom of movement of the citizenry and suspensions of commercial and educational activity; authorizing only activities related to prime necessities such as the purchase of food and medications and attending medical or labor-related centers.

Apart from the possible negative psychological effects as a direct result of the specific confinement conditions, the characteristics of the pandemic and its multiple associated factors qualify the confinement as an adversity of high psychosocial stress, in principle with a greater psychological impact than normative life events (Sandín and Chorot, 2017). Aspects such as ambiguity and uncontrollability of the threat (e.g., the coronavirus), its invisible and unpredictable character, the lethality of the invader or the possible lack of rigor of the information given by the media may, by themselves, generate the same psychological alterations related to perceiving a threat to one's personal health. Preoccupations, fears and/or anxiety of confined people could associate also with other secondary factors such as the health of loved ones, a possible breakdown of health services, labor problems and loss of income, the worldwide expansion of the virus and its economic and social consequences, and so on.

Although previous studies underlined the noxious effects on mental health of quarantines related to viral epidemics (Brooks et al., 2020), as far as we know up to now only one article was published on the psychological effects of COVID-19 in persons under general quarantine (Liu et al., 2020). These authors studied symptoms of posttraumatic stress and sleep disorders in a sample $(N$ $=285$; the online information was collected between January 30 and February 7) of the Chinese population resident in Wuhan and bordering cities in Hubei province during the quarantine imposed in this province (the principle region of China hit by the coronavirus) by the Chinese government on January 23, 2020. The authors found that $7 \%$ of the participants presented symptoms of posttraumatic stress, the greater part associated with acute stress disorders and more common in women than in men. They also found that posttraumatic stress symptomatology was associated with a poorer quality of sleep.

Three studies examined the psychological impact of the outbreak of coronavirus in the general population of China (Cao et al., 2020; Gao et al., 2020) and of India (Roy et al., 2020). Cao et al. studied generalized anxiety disorder symptoms in a Chinese sample of medical 
students of Changzhi $(N=7.143)$ : although authors do not specify the date of collection of online information, the manuscript was received by the journal on March 14 , date on which the pandemic already was remitting in China. The authors found that $0.9 \%$ of the participants suffered important levels of anxiety, $2.7 \%$ moderate levels of anxiety, and $21.3 \%$ levels of mild anxiety. They also noted that living in urban zones, living with parents and having certain family economic stability acted as protective factors against anxiety; in contrast, having family or acquaintances that were infected by the virus acted as a risk factor.

The study of Gao et al. (2020) was conducted with an adult sample from 31 Chinese regions $(N=4.872)$. An evaluation protocol was applied between January 31 and February 2 of 2020; although this was during the confinement period of Hubei province, the data were obtained from the entire Chinese territory ( 31 provinces and autonomous regions of China). The authors investigated the association between exposure to social media and prevalence of anxiety and depression. The study found elevated use of social media by participants (over $80 \%$ ), and elevated levels of generalized anxiety and depression of clinical significance in the sample (22.6\% and $48.3 \%$, respectively). Authors found a positive association between a frequent use of social media and cases of anxiety (or cases of mixed anxiety and depression).

Roy et al. (2020) investigated levels of anxiety over the pandemic, sleep problems, paranoia of suffering COVID-19 infection, and distress related to information provided by the media. The study was carried out with 662 participants of various regions of India, with (online) collection of information from March 22 to 24, 2020 (on March 22, the number of COVID-19-infected in India was just 17, with three virus-caused deaths); although on March 22 the Indian government implemented a curfew intending that the population not leave their homes, this was merely a simulation that only lasted one day between 7 and 21 o'clock. The results of this study indicate that, referring to the previous week, $72 \%$ of participants were preoccupied for themselves and their relatives, and $40 \%$ were paranoiac with respect to a possible COVID-19 infection. Also, 12\% of participants suffered sleep problems. They also found that the excessive information provided by the media was associated with more elevated levels of anxiety, preoccupation with the coronavirus, and sleep problems.

The data of these studies, though very preliminary, tend to suggest a pernicious effect of the pandemic on the emotional wellbeing of people, with a possible impact on anxiety levels, posttraumatic stress, pathological preoccupation, and sleep problems. Although the COVID-19 pandemic has extended over the entire world, not all countries were equally affected. At this moment, Spain has undoubtedly been one of the world's countries most punished by the coronavirus, both for the number of infected and of deceased persons. It also has been one of the most affected by strict measures of quarantine and confinement to the home, including a prohibition for children to go outdoors.

The general objective of this study consisted in examining the psychological impact experienced by the Spanish population, associated with the exceptional confinement situation imposed by the government during the months of March and April of 2020, as well as with the threat of the COVID-19 pandemic. Although the emotional impact can include different emotional reactions which can be more or less specific (Sandín, Chorot y Valiente, 2018), the negative emotions of fear, anxiety and preoccupation usually appear in mixed form during high stress situations and in presence of threats of an unpredictable and uncontrollable nature (Sandín, 2009), each of these predominating more or less in function of characteristics of the situation and the individual. On the basis of this general objective, we aimed to investigate (specific objectives): (a) the emotional impact related to possible fears of the coronavirus, (b) vulnerability/risk and protective factors that may influence the emotional impact, (c) the negative emotional impact (distress) associated with the psychosocial stress situation of confinement and the possibility of establishing an emotional profile of coronavirus, and (d) the possible positive psychological impact of confinement, that is, to assess if confinement could provoke positive effects, such as those related to changes in personal values or ways of interpreting personal or social life aspects.

\section{Method}

\section{Participants}

A sample of a total of 1.161 participants was used. The sample included participants living in the entire Spanish territory (see Table 1). Age range of the participants was from 19 to 84 years $(M=33.4, D T=10.7)$, and 264 $(22.7 \%)$ were men and $898(77.3 \%)$ women. The major part of participants were single $(57 \%)$ or married/living together $(37.5 \%)$, and only $5.5 \%$ were separated or divorced. A high percentage of the sample (68\%) earned less than 25.000 euros per year; thirty percent earned between 25.000 and 75.000 euros. For the remainder of sociodemographic characteristics see Table 2.

Ninety five percent of the sample were students of the Universidad Nacional de Educación a Distancia 
(UNED). The rest were part of the general population. UNED students make up a type of population that is quite similar to the general population except for, obviously, the level of education. All participants completed the protocol online between days 18 and 21 of April 2020. Previously they were informed about the objectives and characteristics of the study, requiring acceptance of the informed consent. The study was approved by the bioethics committee of the UNED.

Table 1. Distribution of the sample according to Spanish Communities $(N=1.161)$

\begin{tabular}{lcc}
\hline \multicolumn{1}{c}{ Community } & Frequency & Percentage \\
\hline Andalusia & 178 & 15.3 \\
Aragon & 91 & 7.8 \\
Asturias & 33 & 2.8 \\
Balearic Islands & 13 & 1.1 \\
Canary Islands & 42 & 3.6 \\
Cantabria & 19 & 1.6 \\
Castile and León & 65 & 5.6 \\
Castile-La Mancha & 57 & 4.9 \\
Catalonia & 59 & 5.1 \\
Extremadura & 43 & 3.7 \\
Galicia & 95 & 8.2 \\
La Rioja & 4 & 0.3 \\
Community of Madrid & 227 & 19.6 \\
Region of Murcia & 36 & 3.1 \\
Navarre & 37 & 3.2 \\
Basque Country & 46 & 4.0 \\
Valencian Community & 108 & 9.3 \\
Ceuta and Melilla & 8 & 0.7 \\
\hline
\end{tabular}

\section{Assessment instruments}

Coronavirus Psychological Impact Questionnaire $(C P I Q)$. This is a self-report questionnaire designed to assess the psychological impact associated with the COVID-19 pandemic. It includes several initial questions on sociodemographic characteristics and 9 independent scales: (1) Experience with Coronavirus (ECOVI); (2) Media Exposure (ME); (3) Quarantine Related Behaviors (CRB); (4) Use of Preventive Behaviors (UPB); (5) Fear of Coronavirus Scale (FCS); (6) Distress Scale (DS); (7) Posttraumatic Stress Symptoms Scale (PSSS); (8) Coronavirus Interference Scale (CIS); and (9) Positive Experiences in Adversity Scale (PEAS) (for a complete description of the questionnaire, see Appendix I). Regarding the present study, sociodemographic questions and the scales ME, FCS, DS and PEAS were used.

Media Exposure (ME). This is a 4-item scale designed to assess media exposure, including television, internet, social media, and newspapers. The scale includes three possible answers ranged from 1 («Little to nothing» to 3 («The main part of the day»).

Fear of Coronavirus Scale (FCS). It includes 18 items related to fears of and preoccupations with psychosocial aspects of coronavirus, such as the fear that some relative gets the virus, or the fear or preoccupation that food or basic products will become scarce. The instrument is answered with an intensity scale of five points, ranged from 1 («Not at all or very little») and 5 («Very much or extremely»). To examine possible factorial dimensions of the fears to coronavirus, we previously conducted an exploratory factor analysis of the scale. The structure obtained was very consistent and revealed the following four fear factors associated with coronavirus: (F1) Fear of infection, disease and death (Items 1,2,3,4,5,7,10,11,17); (F2) Fear of scarcity of basic consumer products (Items 12, 13, 14); (F3) Fears of social isolation (Items 15, 16, 18 ); and (F4) Fears related to work and income (Items 6, $8,9)$. Reliability coefficients were as follows: alfa $(\alpha)=$ .89 , rho $(\rho)=.89$ (EMC-total); $\alpha=.87$, omega $(\omega)=.88$ (Subscale F1); $\alpha=.79, \omega=.81$ (Subscale F2); $\alpha=.72$, $\omega=.74$ (Subscale F3); $\alpha=.80, \omega=.83$ (Subscale F4).

Distress Scale (DS). This is a 10 -item scale that assesses 10 types of negative emotional experiences and sleep problems that generally are caused by high psychosocial stress situations. The participant responds on a frequency scale of five points, ranging from 1 («Never or almost never») to 5 («Almost always»). We found the following reliability coefficients: $\alpha=.93, \omega=.93$.

Positive Experiences in Adversities Scale (PEAS). It consists of 11 items about positive experiences that some persons have during adverse periods with high psychosocial stress. The response scale ranged from 1 («Not applicable to me») to 5 («Totally applicable to me»). The internal consistency of the scale is high: $\alpha=$ $.84, \omega=.87$.

Intolerance of Uncertainty Scale-12 (IUS-12; Carleton, Norton y Asmundson, 2007). The Spanish version by Sandín, Chorot, Valiente and Pineda (2012) was used. It concerns a self-report scale of 12 items that assess intolerance regarding ambiguous situations and uncertainty of future events. The scale is answered ranging from 1 («Not characteristic of me») to 5 («Totally characteristic of me»). Evidence has been provided on its excellent psychometric properties (Pineda, 2018). In the present study the following reliability values were obtained: $\alpha=.94, \rho=.94$.

Positive and Negative Affect Schedule (PANAS). The Spanish version validated by Sandín et al. (1999) was applied. It consists of 20 items, 10 referring to positive affect and 10 to negative affect. Each item is valued on an intensity scale ranged from 1 («Very slightly or not at 
all») to 5 («Extremely»). The psychometric properties of this version are excellent. In the present study, the following reliability coefficients were obtained: $\alpha=.91$, $\omega=.92$ (Scale of positive affect) y $\alpha=.90, \omega=.91$ (Scale of negative affect).

\section{Statistical analysis of the data}

Apart from basic statistics (means and $D T \mathrm{~s}$ ), an exploratory factorial analysis was carried out of the Fear of Coronavirus Scale (FCS) on the basis of polychoric correlations and in the least squares extraction method. The number of factors was done by parallel analysis, and geomin oblique rotation was applied. To estimate the reliability of the scales (internal consistency) we calculated the coefficients rho $(\rho)$, omega $(\omega)$, and the traditional coefficient alfa $(\alpha)$. Frequency analyses were computed using Pearson's $\chi^{2}$ and the non-parametric cross-tabulation test (for multivariate frequency distributions). The correlations between the variables were calculated with Pearson and Spearman correlation coefficients. To elaborate the predictive models of fear of coronavirus based on the vulnerability/risk and protective factors, we applied several series of multiple regression analysis based on stepwise approach to determine the best predictors. The analyses were done with the statistical programs SPSS.25 and EQS 6.3.

\section{Results}

\section{Sociodemographic characteristics}

The primary sociodemographic characteristics of the sample are indicated in Table 2. As can be seen, participants live mainly in urban areas, their homes have no private garden, and their family nucleus does not exceed three persons. A relevant percentage of participants live with a person with a serious chronic illness $(18.2 \%)$, or a dependent person who requires considerable attention (7.8\%). The main part of subjects did not have to go to work outside the home (75.6\%). An important percentage $(9 \%)$ works outside the home as healthcare professionals.

\section{Common fears associated with coronavirus}

In order to examine the most common fears of coronavirus we calculated the answers of the participants to the Fear of Coronavirus Scale (FCS). Of the total sample of participants, the frequency was calculated of those that answered to have had much or very much fear and preoccupation to each item of the scale (see Table 3).
Tabla 2. Características sociodemográficas de la muestra durante el confinamiento $(N=1.161)$

\begin{tabular}{|c|c|c|}
\hline Variable & $n$ & $\%$ \\
\hline \multicolumn{3}{|l|}{ Location of housing: } \\
\hline Urban (city) & 752 & 64.8 \\
\hline Rural (village) & 409 & 35.2 \\
\hline \multicolumn{3}{|l|}{ House with private garden } \\
\hline Yes & 256 & 22.0 \\
\hline No & 905 & 78.0 \\
\hline \multicolumn{3}{|l|}{ Income level (yearly) } \\
\hline Up to $10.000 €$ & 293 & 25.2 \\
\hline $10.000-25.000 €$ & 504 & 43.4 \\
\hline $25-000-40.000 €$ & 234 & 20.2 \\
\hline More than $40.000 €$ & 130 & 11.2 \\
\hline \multicolumn{3}{|l|}{ Family life } \\
\hline Single person & 125 & 10.8 \\
\hline $2-3$ persons & 645 & 55.6 \\
\hline Four or more & 391 & 33.7 \\
\hline \multicolumn{3}{|c|}{ Lives with child/children less than 12 years old } \\
\hline Yes & 201 & 17.3 \\
\hline No & 950 & 82.7 \\
\hline \multicolumn{3}{|c|}{ Lives with a chronically ill person } \\
\hline Yes & 211 & 18.2 \\
\hline No & 959 & 81.8 \\
\hline \multicolumn{3}{|c|}{$\begin{array}{l}\text { Lives with a dependent person that requires } \\
\text { considerable attention }\end{array}$} \\
\hline Yes & 90 & 7.8 \\
\hline No & 1071 & 92.2 \\
\hline \multicolumn{3}{|l|}{ Has to leave home to work } \\
\hline Yes & 283 & 24.4 \\
\hline No & 878 & 75.6 \\
\hline \multicolumn{3}{|l|}{ Health worker } \\
\hline Yes & 104 & 9.0 \\
\hline No & 1057 & 91.0 \\
\hline \multicolumn{3}{|c|}{$\begin{array}{l}\text { Member of security forces supporting health or } \\
\text { compliance of confinement activities }\end{array}$} \\
\hline Yes & 47 & 4 \\
\hline No & 1114 & 96 \\
\hline
\end{tabular}

Note. All $\chi^{2}$ tests of frequency distribution for the variables resulted statistically significant $(* p<.001)$.

The table separately indicates the values that correspond to the total sample and those for the subsamples of men and women.

As can be seen in the table, items with major impact (for more than $40 \%$ of participants) correspond with the dimension related to fear of infection, disease or death. Nearly half of participants $(49 \%)$ had very high fear and preoccupation levels associated with a family member's death. The items that generated higher impact were related to family (Items 3, 4, 10), less than with the threat to oneself (Items 1, 2, and 11). Very frequent is the 
Table 3. The 10 most frequent fears associated with coronavirus during confinement (by gender)

\begin{tabular}{|c|c|c|c|c|}
\hline \multirow{2}{*}{ Item of the FCS } & \multicolumn{4}{|c|}{$\begin{array}{l}\text { Percentage of individuals that experienced } \\
\text { much or very much fear }\end{array}$} \\
\hline & $\begin{array}{l}\text { Total sample } \\
(N=1.161)\end{array}$ & $\begin{array}{l}\text { Women } \\
(n=898)\end{array}$ & $\begin{array}{c}\text { Men } \\
(n=263)\end{array}$ & $\chi^{2}(1)$ \\
\hline 1 (4). That a close relative may die & 49.0 & 54.0 & 31.9 & $39.6^{* * *}$ \\
\hline 2 (3). That a close relative may be infected & 43.0 & 47.9 & 26.2 & $38.9 * * *$ \\
\hline 3 (5). That the coronavirus will continue to spread & 42.7 & 46.9 & 28.5 & $28.1 * * *$ \\
\hline 4 (15). Not being able to see family or close friends & 41.3 & 45.4 & 27.0 & $28.5 * * *$ \\
\hline 5 (10). Could contaminate a close relative & 40.2 & 44.1 & 27.0 & $24.7 * * *$ \\
\hline 6 (6). To lose job or part of job & 34.5 & 26.3 & 16.0 & $11.8 * * *$ \\
\hline 7 (9). That a close relative loses the job & 23.9 & 37.9 & 23.2 & $19.3 * * *$ \\
\hline 8 (8). To lose income & 29.5 & 32.0 & 20.9 & $11.9 * * *$ \\
\hline 9 (18). To be socially isolated & 24.5 & 26.6 & 17.1 & $9.9 * *$ \\
\hline 10 (17). To see or hear news on coronavirus & 20.8 & 24.9 & 6.8 & $40.1 * * *$ \\
\hline 11 (7). That you or someone of the family has to leave the house & 18.4 & 20.3 & 12.2 & $8.87 * *$ \\
\hline 12 (13). Having to go to the emergency room (for accident, illness, etc.) & 17.7 & 19.5 & 11.4 & $9.1 * *$ \\
\hline 13 (11). To get sick or an existing illness getting worse & 16.9 & 18.9 & 9.9 & $11.8 * * *$ \\
\hline 14 (1). To get infected by coronavirus & 15.0 & 16.8 & 8.7 & $10.4 * *$ \\
\hline $\begin{array}{l}15 \text { (16). Not being able to celebrate important occasions (christenings, } \\
\text { weddings, etc.) }\end{array}$ & 12.1 & 13.7 & 6.5 & $10.1 * *$ \\
\hline 16 (2). To die owing to coronavirus & 9.8 & 11.2 & 4.9 & $9.1^{* *}$ \\
\hline 17 (12). That food or basic products become scarce & 9.1 & 10.7 & 3.8 & $11.6^{* * *}$ \\
\hline 18 (14). Not having necessary things in the home (food, etc.) & 8.8 & 10.1 & 4.2 & $8.9 * *$ \\
\hline
\end{tabular}

Note. Fears are ordered by frequency level in the total sample (in parentheses the item number of FSC is given). The 10 most common fears of coronavirus are highlighted. FCS $=$ Fear of Coronavirus Scale. $* * p<.01, * * * p<.001$.

fear that the coronavirus will continue spreading (Item 5, $42.7 \%$ ) and somewhat less frequent the item referring to having to leave the house (Item 7).

The following fears or preoccupations in the ranking correspond to labor situations (i.e., the dimension of work and income; Items 6-8). The fears that make up the dimension of fears of social isolation (Items 15, 16, and 18) are irregularly distributed: a very frequent fear is not being able to see close relatives or close friends (Item 15), the preoccupation of being socially isolated has a relatively high frequency (Item 18), and the fear or anxiety of not being able to celebrate important events on account of confinement conditions had lesser impact (Item 16). Finally, the items that correspond with the dimension of fear for not covering first necessities (Items 12,13 and 14) found places in the lowest positions of the ranking, although the percentages of affected persons resulted relevant (for instance, close to $20 \%$ of the female population feared excessively for the possibility of having to go to emergency services for a health motive other than coronavirus; Item 13). To sum up, and taking as reference the four fear dimensions, it can be stated that the dimension that is most affected is related to possible infection or death of close relatives, followed by the dimensions of work/income and social isolation; the smallest impact is associated with the dimension of basis needs.

Comparing the scores for groups of men and women separately, we observed a significant higher impact in women of all types of fears or preoccupations (see Table 3 ). One in two women reported to have had much fear or extreme fear that some close relative might die (54\%), that some close relative might be infected (47.9\%), that the coronavirus would spread (46.9\%), o not being able to see close relatives or close friends $(45.4 \%)$. In the group of men, the pattern of these fears applied to one in three men. In other cases, the difference between men and women is even larger, with the percentage of women that suffer these fears doubling or even more than doubling that of men: for example, the extreme 
Table 4. The 10 most frequent fears associated with coronavirus during confinement (by age)

\begin{tabular}{|c|c|c|c|c|}
\hline \multirow{3}{*}{ FCS item } & \multicolumn{4}{|c|}{$\begin{array}{l}\text { Percentage of individuals that experienced } \\
\text { much or very much fear }\end{array}$} \\
\hline & \multicolumn{4}{|c|}{ Age groups (years) } \\
\hline & $\begin{array}{c}19-30 \\
(N=572)\end{array}$ & $\begin{array}{c}31-50 \\
(n=500)\end{array}$ & $\begin{array}{c}51-84 \\
(n=90)\end{array}$ & $\chi^{2}(2)$ \\
\hline 1 (4). That a close relative will die & 55.9 & 44.6 & 30.0 & $27.6 * * *$ \\
\hline 2 (3). That a close relative will get infected & 48.3 & 39.82 & 26.7 & $18.5 * * *$ \\
\hline 3 (5). That coronavirus continues to spread & 45.5 & 40.0 & 40.0 & 3.6 \\
\hline 4 (15). Not being able to see close relatives or friends & 49.2 & 34.0 & 31.1 & $29.5 * * *$ \\
\hline 5 (10). Could infect a close relative & 45.4 & 37.6 & 22.2 & $19.8 * * *$ \\
\hline 6 (6). To lose the job or part of it & 26.3 & 23.0 & 14.4 & $6.4^{*}$ \\
\hline 7 (9). That a close relative loses the job & 40.3 & 28.0 & 34.4 & $17.7 * * *$ \\
\hline 8 (8). To lose income & 31.5 & 28.4 & 22.2 & 3.7 \\
\hline 9 (18). To be socially isolated & 31.9 & 17.8 & 14.4 & $33.8 * * *$ \\
\hline 10 (17). See/hear news on coronavirus & 23.1 & 18.4 & 18.9 & 3.8 \\
\hline 11 (7). That you or someone of the family has to leave the home & 18.4 & 19.6 & 12.2 & 2.7 \\
\hline 12 (13). To have to go to the emergency room (for accident, illness, etc.) & 17.5 & 17.6 & 18.9 & 0.1 \\
\hline 13 (11). To become ill or that an existing illness gets worse & 15.4 & 19.2 & 13.3 & 3.6 \\
\hline 14 (1). To get infected with coronavirus & 13.8 & 17.2 & 10.0 & 4.2 \\
\hline $\begin{array}{l}15 \text { (16). To not be able to celebrate important occasions (christenings, } \\
\text { communions, weddings, etc.) }\end{array}$ & 14.5 & 9.8 & 8.9 & $6.5^{*}$ \\
\hline 16 (2). Dying on account of coronavirus & 8.8 & 11.6 & 6.7 & 3.5 \\
\hline 17 (12). That food or other first necessity products get scarce & 9.6 & 8.6 & 8.9 & 0.4 \\
\hline 18 (14). Not having necessary things in the home (food, etc.) & 10.5 & 7.0 & 7.8 & 4.2 \\
\hline
\end{tabular}

Note. Fears are ordered by level of frequency in the total sample (in parentheses the item number of the FCS is given). The 10 most common fears of coronavirus are highlighted. FCS $=$ Fear of Coronavirus Scale. ${ }^{*} p<.05,{ }^{* * *} p<.001$.

fear produced by seeing or hearing news related to the coronavirus was experienced by $24.9 \%$ of women and $6.8 \%$ of men (see Table 3 for more information).

In order to compare the frequency according to age, the following three age groups were established: 1930 years, 31-50 years, and 51-80 years. The obtained results are shown in Table 4. In this table we can observe significant differences according to age in the frequency distribution for some fears (for 8 types of fears) but not for all. Differences are present for certain fears that correspond with some dimensions of the FCS scale, although not for any item of the subscale of fears of shortness of basic products (first necessities). Three of the fears for which we found significant differences correspond to the category of fears of infection, disease and death (Items 3, 4 and 10), three correspond with the fear dimension of social isolation (Items 15, 16 and 18), and two with fears related to work and income (Items 6 and 9). An important result was that, in general, the highest percentages are associated with the younger age groups, especially the group of 19-30 years, which denotes that this group presents a higher vulnerability.

\section{Risk/vulnerability and protective factors}

In order to examine a possible protective or risk/vulnerability role of (1) sociodemographic characteristics (see Table 1), (2) exposure to social media, and (3) differences in personality (positive and negative affect, and intolerance of uncertainty) on fear of and preoccupation with coronavirus, we applied several series of regression analysis, using as dependent variables the total score in FCS and the scores in each of the four fear categories. We started conducting a selection of the sociodemographic variables, applying the stepwise selection method. These selected variables, and those of affect (positive and negative) and intolerance of uncertainty (individual difference variables), are the 
vulnerability/risk and protective variables as included in Table 5. In addition, the sociodemographic variables of age and gender also were included in the final regression analysis (Table 6). Regarding the gender variable, 1 is assigned to male and 2 to female.

Correlations of fear dimensions with personality variables (Pearson's correlations) and sociodemographics (Spearman's correlations) were computed. As can be seen in Table 5, there are some patterns of correlation between risk or vulnerability variables and fear of coronavirus. Intolerance of uncertainty, negative affect and media exposure correlate positively and significantly with all fear variables. Living with a chronically ill person also correlates in this direction with all fear variables, except with fear of social isolation. Other variables that also correlated positively with fears are living with dependent persons and living with children less than 12 years old (this last variable only correlates with fear of shortness of first necessities). Four variables present patterns of negative correlation, which are income level, working outside the home, have a private garden with the home, and positive affect.

In Table 6 we present the results of the regression analyses carried out with these variables (to which were added the age and gender variables). The risk/ vulnerability and protective variables were included together in the regression equation as independent variables, conducting a multiple stepwise regression analysis for each of the five dependent variables (fear variables), with the aim of selecting the best predictive model for each one. Each regression equation thus includes 12 independent variables, of which - and based upon the signs of the correlations - we started off with 5 protective factors (age, income level, work outside the home, have a private garden, and positive affect) and 6 risk or vulnerability factors (negative affect, intolerance of uncertainty, media exposure, and living with children less than 12 years old, with dependent persons and with chronically ill persons). Finally, to be of female gender is considered a vulnerability factor.

This table describes the predictive model of fears of coronavirus corresponding to the general fears level, and each one of the four fear types. Every model, corresponding with each dependent variable, indicates the independent variables that form part of the model and the type of relation established by each independent variable with the dependent variable (the regression coefficient with negative sign indicates that the particular independent variable is a protective variable; and the opposite when the coefficient is positive). We can see that the predictors usually are risk or vulnerability factors, more than protective factors. The model that refers to general fear scores (total score in the scale) included 5 risk/vulnerability factors and a protective factor (income level). In this model, the variable that appears to be most relevant is intolerance of uncertainty, followed by media exposure, gender (i.e., be of female gender), negative affect, and living with persons with a chronic illness.

Although the models that refer to the different fear categories present a certain likeness to the general model, they also have their own characteristics as a function of the fear type. One common characteristic is

Table 5. Correlations between types of fear of coronavirus and sociodemographic and personality variables $(N=1.161)$

\begin{tabular}{|c|c|c|c|c|c|}
\hline \multirow{2}{*}{ Vulnerability/risk and protective variables } & \multicolumn{5}{|c|}{ FCS } \\
\hline & InDiDe & ShoBa & SoIso & WorInc & Total \\
\hline Income level & $-.11 * * *$ & $-.08 *$ & $-.09 * *$ & $-.23 * * *$ & $-.16^{* * *}$ \\
\hline Private garden with home & -.02 & .00 & $-.09 * *$ & $-.07 *$ & -.05 \\
\hline Living with children less than 12 years old & -.02 & $.08 * *$ & -.04 & -.04 & -.02 \\
\hline Living with chronically ill persons & $.21 * * *$ & $.13 * * *$ & .01 & $.10 * *$ & $.18 * * *$ \\
\hline Living with dependent persons & $.10 * *$ & $.09 * *$ & .04 & .05 & $.09 * *$ \\
\hline Working outside the house & -.05 & $-.13 * * *$ & -.04 & $-.19 * * *$ & $-.12 * * *$ \\
\hline Media exposure (ME) & $.22 * * *$ & $.16^{* * *}$ & $.21 * * *$ & $.17 * * *$ & $.25 * * *$ \\
\hline Intolerance of uncertainly (IUS) & $.36^{* * *}$ & $.33 * * *$ & $.27 * * *$ & $.31 * * *$ & $.42 * * *$ \\
\hline Positive affect (PANAS-P) & $-.08 * *$ & $-.09 * *$ & $-.11 * * *$ & $-.12 * * *$ & $-.12 * * *$ \\
\hline Negative affect (PANAS-N) & $.34 * * *$ & $.25 * * *$ & $.26^{* * *}$ & $.28 * * *$ & $.39 * * *$ \\
\hline
\end{tabular}

Note. The correlations between fear variables were calculated applying Pearson's correlation (personality variables) and Spearman's correlation (sociodemographic variables). FCS = Fear of Coronavirus Scale; InDiDe = Fear of infection, disease and death; Shoba $=$ Fear of shortness of basis products (products of first necessity); SoIso= Fears of social isolation; WorInc $=$ Fears related to work and income. ${ }^{*} p<.05,{ }^{* *} p<.01,{ }^{* * *} p<.001$. 
Table 6. Predictive models of coronavirus fears. Multiple regression stepwise analyses $(N=1.161)$

\begin{tabular}{|c|c|c|c|c|c|}
\hline & $R^{2}$ & $B$ & $E T B$ & Beta & $r$ parcial \\
\hline Total FCS score & $.29 * * *$ & & & & \\
\hline Intolerance of uncertainty & & .33 & .04 & $.26^{* * *}$ & .24 \\
\hline Media exposure & & 1.96 & .25 & $.19 * * *$ & .22 \\
\hline Gender & & 4.53 & .77 & $.15^{* * *}$ & .17 \\
\hline Negative affect (PANAS-N) & & .28 & .05 & $.17 * * *$ & .15 \\
\hline Living with chronically ill persons & & 4.14 & .83 & $.13 * * *$ & .14 \\
\hline Income level & & -.92 & .35 & $-.07 * *$ & -.08 \\
\hline Fear of infection/disease/death & $.24 * * *$ & & & & \\
\hline Intolerance of uncertainty (IUS) & & .16 & .02 & $.22 * * *$ & .19 \\
\hline Living with chronically ill persons & & 3.26 & .50 & $.17^{* * *}$ & .19 \\
\hline Media exposure & & .95 & .15 & $.16^{* * *}$ & .18 \\
\hline Gender & & 2.75 & .46 & $.15^{* * *}$ & .17 \\
\hline Negative affect (PANAS-N) & & .18 & .03 & $.18^{* * *}$ & .15 \\
\hline Positive affect (PANAS-P) & & -.07 & .03 & $-.07 *$ & -.07 \\
\hline Fear of shortness of first necessities & $.15^{* * *}$ & & & & \\
\hline Intolerance of uncertainty (IUS) & & .08 & .01 & $.31 * * *$ & .31 \\
\hline Media exposure & & .26 & .06 & $.12 * * *$ & .13 \\
\hline Living with chronically ill persons & & .69 & .19 & $.11^{* * *}$ & .11 \\
\hline Working outside the home & & -.61 & .17 & $-.10 * *$ & -.10 \\
\hline Living with children less than 12 years old & & .64 & .19 & $.09^{* *}$ & .09 \\
\hline Fear of social isolation & $.16^{* * *}$ & & & & \\
\hline Intolerance of uncertainty (IUS) & & .04 & .01 & $.14 * * *$ & .12 \\
\hline Media exposure & & .41 & .06 & $.18 * * *$ & .19 \\
\hline Age & & -.04 & .01 & $-.14 * * *$ & -.14 \\
\hline Negative affect (PANAS-N) & & .05 & .01 & $.13 * * *$ & .11 \\
\hline Gender & & .59 & .19 & $.09 * *$ & .09 \\
\hline Private garden with the home & & -.56 & .19 & $-.08^{*}$ & -.09 \\
\hline Fears related to work and income & $.18^{* * *}$ & & & & \\
\hline Intolerance of uncertainly (IUS) & & .05 & .01 & $.17 * * *$ & .15 \\
\hline Income level & & -.52 & .10 & $-.15 * * *$ & -.16 \\
\hline Media exposure & & .33 & .07 & $.13 * * *$ & .14 \\
\hline Working outside the home & & -.94 & .21 & $-.12 * * *$ & -.13 \\
\hline Negative affect (PANAS-N) & & .05 & .01 & $.12 * * *$ & .10 \\
\hline Gender & & .56 & .22 & $.07 *$ & .08 \\
\hline Private garden with the home & & -.51 & .22 & $-.06 *$ & -.07 \\
\hline Living with chronically ill persons & & .52 & .23 & $.06^{*}$ & .07 \\
\hline
\end{tabular}

Note. For each analysis the indicated variables correspond to the last step and in the order of selection. Dependent variables are given in italics. $* \mathrm{p}<.05, * * \mathrm{p}<.01, * * * \mathrm{p}<.001$.

intolerance of uncertainty, appearing in all models as the main predictive variable. The variable of media exposure acts in a similar way, although with less predictive value. Gender and negative affect predict all fear types, except fear related to shortness of basic necessities. Living with chronically ill persons also predicts all fear types, except fear of social isolation. Living with children less than 12 years old only predicts fears related to fear of shortness of basic necessities.

Concerning the predictive role of protective factors, their implication is more variable and less consistent.
Thus, several factors appear to relate only to specific types of fear. Income level, work outside the home, and having a private garden predicted several fear types. Age predicts fear of social isolation. The only protective factor that predicts fear of infection/disease/death is positive affect, with weak predictive power. For more details, see Table 6 .

Given the special relevance the intolerance of uncertainty appears to have on coronavirus fears we conducted an analysis of variance to examine the degree to which this variable resulted efficacious for differencing 
the scores in fears level. To this end we established two groups (high versus low intolerance; the groups were established according to if the participant scored an SD in the IUS above $[n=205]$ or below $[n=218]$ the mean, respectively. As was expected, the effect of uncertainty intolerance was statistically significant $(\mathrm{F}=166.3, \mathrm{p}<$ $.001)$, after controlling for the effect of age and gender. Figure 1 indicates the mean scores in general level of fear of coronavirus as a function of the individual differences in uncertainty intolerance. As the figure indicates, the individuals with low levels of intolerance appear to be protected from the negative impact of coronavirus.

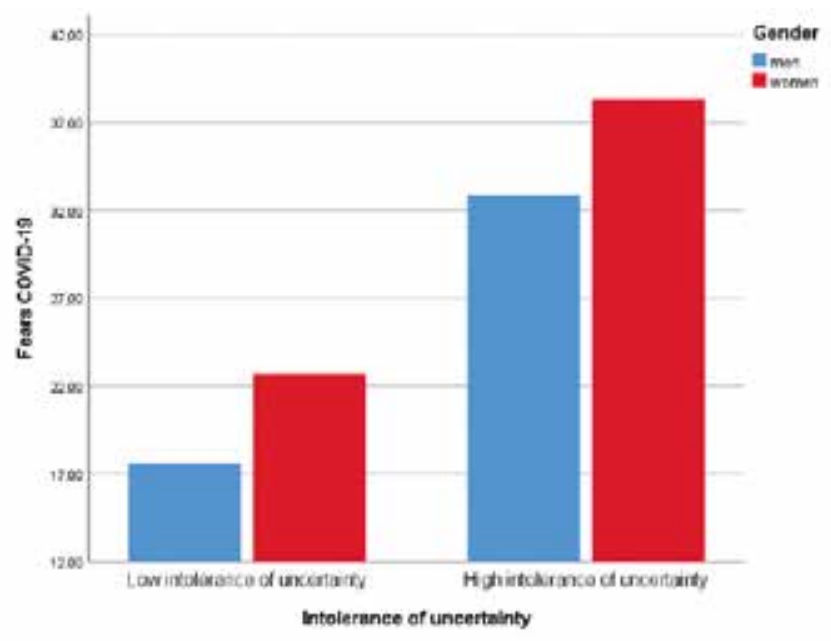

Figure 1. Mean scores on the Fear of Coronavirus Scale as a function of the level of intolerance of uncertainty (total score in the IUS) (groups of high and low intolerance of uncertainty).

\section{Emotional profile associated with COVID-19}

It appears that the fear related to coronavirus consists of a fundamental emotional reaction. However, it would also be interesting to examine the emotional states habitually experienced by individuals during the confinement stage, a time period of high threat and general distress. For this purpose the Distress Scale (DS) was applied, a scale that permits to assess emotional experiences related to confinement and COVID-19.

Figure 2 presents the results related to the answers given to the DS by men and women. The y-axis reflects the percentage of participants that responded to the scale indicating to have experienced the emotion with the highest frequency («Many times» or «Almost always»). As can be seen, the scale assesses 9 negative emotions and the experience of sleep problems. There are marked differences between both groups, and we found statistically significant differences for all of the variables $(p<.001)$. Nevertheless, the profiles are very similar, as in both groups the highest percentages correspond to preoccupation $(34.7 / 15.2 \%)$, stress (33/12.5\%), hopelessness (29.3/15.6\%), depression $(29.7 / 9.9 \%)$ and sleep problems (30/13.3\%). By contrast, also in both groups, the lowest scores were reported on anger/irritability (14.3/4.2) and feelings of loneliness $(16.3 / 8.4 \%)$. We found intermediate levels on anxiety (28/9.5\%), nervousness $(23.6 / 11 \%)$ and restlessness (26.9/12.2\%). The great difference between men and women as to experiencing these emotions is striking, suggesting that women are considerably more emotionally vulnerable to confinement effects than men. Although some authors have not found significant differences between men and women on anxiety and depression (e.g. Barrera-Herrera et al., 2019), one plausible explanation is that the differences are marked when the situation is extremely stressful or adverse.

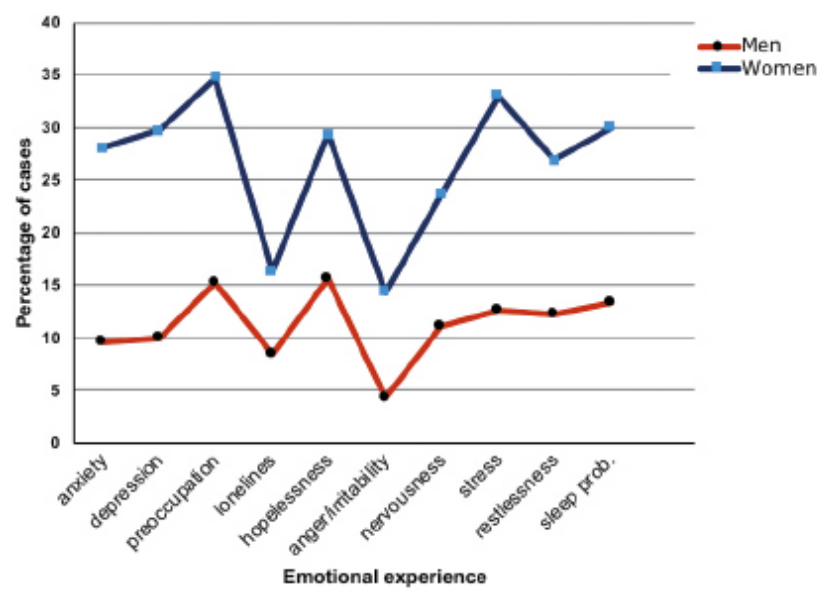

Figure 2. Emotional profile associated with COVID-19 in the groups of men and women.

The results according to age groups are represented in Figure 3. The general profile pattern is similar in the three groups, although the scores are much higher for the lower age group (between 19-30 years). We found a statistically significant association between age and frequency of cases for all variables $(p<.001$; for the preoccupation variable $p<.05$ ). A noticeable change occurs in the lower age group, where sleep problems reach much higher levels than those observed in the other two groups. Otherwise the pattern is very similar to that of Figure 2, prevailing cases of preoccupation (33.8/27.4/24.5\%), stress, $(38 / 19.8 / 14.4 \%)$, hopelessness (33.5/19.2/16.7\%), depression (32.4/18.2/18.9), and sleep problems (36.4/17/12.2\%); also being inferior cases of anger/irritability (16.8/7.4/6.7\%) and feelings of loneliness (19.6/9.6/8.9\%). For the rest of emotions, 
the obtained percentages are 29.9/18.4/14.4\% (anxiety), 29.1/18.8/15.6\% (restlessness), and 25.7/16.2/14.4\% (nervousness) (see Figure 3).

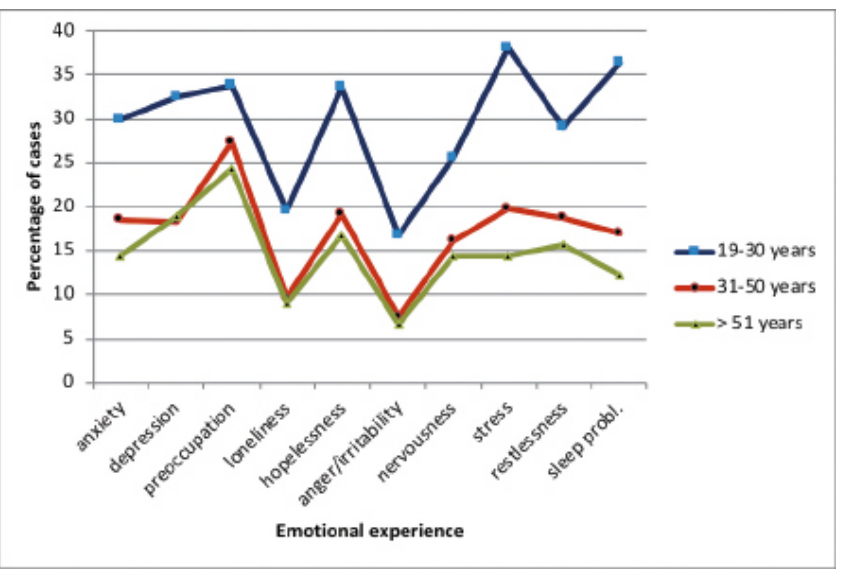

Figure 3. Emotional profile associated with COVID-19 by age groups.

\section{Positive psychological effects associated with confine- ment for coronavirus}

Although we assume that the primary effects of the psychological impact of confinement are adverse and affect primarily negative emotions, on the basis of the hypothesis that confinement leads us to having new experiences we wanted to know to what extent these could have positive effects in the individual. For this we relied on the data obtained with the Positive Experiences in Adversity Scale (PEAS). The frequencies were calculated for the participants who scored 4 or 5 in the scale (this is «Very applicable to me» or «Totally applicable to me»). The results of these analyses are indicated in Table 7.

As can be seen in the table, an elevated percentage of participants enjoyed new positive experiences to a high degree, such as to learn to value outdoor activities more (more than $50 \%$ of the sample), to take more interest in people, to value more the importance of interpersonal relationships, to be more interested in the future, to appreciate the value of dedicating more time to the family, and so on. Some participants also appreciated discovering new hobbies or to practice more religious or spiritual activity (see Table 7). A striking point is that, save for the experience of becoming more religious or spiritual, the percentage in the group of women is superior to that of men for all types of positive experiences indicated in the table,. Nevertheless, the order is which the percentages are distributed is very similar in both groups.

In Table 8 we present the results in function of the three age groups. It can be seen that significant differences are found between each group for more than half of the experiences. The pattern is clear and consistent, and the highest percentages are found in the groups of less age, especially in the youngest group (19-30 years).

Table 7. Positive confinement effects: Percentage of participants that lived to a very high or maximum degree the indicated positive experiences (according to gender)

\begin{tabular}{|c|c|c|c|c|}
\hline \multirow[b]{2}{*}{ Type of positive experience (PEAS item) } & \multicolumn{4}{|c|}{ Percentage } \\
\hline & $\begin{array}{r}\text { Total sample } \\
(N=1.161)\end{array}$ & $\begin{array}{l}\text { Women } \\
(n=898)\end{array}$ & $\begin{array}{c}\text { Men } \\
(n=263)\end{array}$ & $\chi^{2}(1)$ \\
\hline 1 (11). I learned to value outdoor activities more & 50.6 & 53.8 & 39.5 & $22.9 * * *$ \\
\hline 2 (5). I have been more interested in people & 36.8 & 41.1 & 22.1 & $40.2 * * *$ \\
\hline 3 (10). I learned to value personal relationships more & 36.6 & 40.0 & 20.5 & $46.8 * * *$ \\
\hline 4 (8). I am more interested in the future than before & 33.6 & 36.6 & 23.2 & $24.3 * * *$ \\
\hline 5 (6). I liked spending more time with my family & 31.3 & 33.7 & 22.8 & $12.4^{* *}$ \\
\hline 6 (9). I learned to appreciate more what we have & 31.2 & 34.6 & 19.4 & $28.7 * * *$ \\
\hline 7 (1). I learned to better organize my free time & 28.4 & 30.0 & 23.2 & $11.1^{* *}$ \\
\hline 8 (7). I liked having more free time for myself & 23.8 & 25.4 & 18.3 & $10.2 * *$ \\
\hline 9 (4). I now value and appreciate things I did not care about before & 22.1 & 24.6 & 13.7 & $22.5 * * *$ \\
\hline 10 (2). I discovered new hobbies or activities & 8.3 & 10.0 & 2.3 & $25.1 * * *$ \\
\hline 11 (3). I have become more religious or spiritual & 3.3 & 3.7 & 1.9 & 2.1 \\
\hline
\end{tabular}

Note. The experiences are in order of more to less frequency in the total sample (the PEAS item number is indicated in parentheses). PEAS $=$ Positive Experiences in Adversity Scale. ${ }^{* *} \mathrm{p}<.01, * * * p<.001$. 
Table 8. Positive effects of confinement: Percentage of participants that lived to a very high or maximum degree the indicated positive experiences (according to age)

\begin{tabular}{|c|c|c|c|c|}
\hline \multirow[b]{2}{*}{ Type of positive experience (PEAS item) } & \multicolumn{4}{|c|}{ Percentage } \\
\hline & $\begin{array}{c}19-30 \text { years } \\
(N=572)\end{array}$ & $\begin{array}{c}31-50 \text { years } \\
(n=500)\end{array}$ & $\begin{array}{c}\text { 51-84 years } \\
(n=90)\end{array}$ & $\chi^{2}(2)$ \\
\hline 1 (11). I learned to value outdoor activities more & 60.2 & 43.0 & 31.1 & $46.4 * * *$ \\
\hline $2(5)$. I take more interest in people & 39.8 & $33 . .8$ & 34.4 & 4.3 \\
\hline 3 (10). I have learned to value personal relationships more & 45.5 & 26.8 & 21.1 & $49.7 * * *$ \\
\hline 4 (8). I am more interested in the future than before & 39.9 & 29.0 & 18.9 & $23.7 * * *$ \\
\hline 5 (6). I liked spending more time with my family & 28.9 & 33.0 & 31.1 & 1.3 \\
\hline 6 (9). I learned to appreciate more what we have & 36.4 & 27.0 & 21.0 & $15.6 * * *$ \\
\hline 7 (1). I learned to better organize my free time & 29.9 & 27.6 & 23.3 & 1.9 \\
\hline 8 (7). I liked having more free time for myself & 26.8 & 22.0 & 14.4 & $8.1 *$ \\
\hline 9 (4). I now value and appreciate things I did not care about before & 27.3 & 17.6 & 14.4 & $17.9 * * *$ \\
\hline 10 (2). I discovered new hobbies or activities & 10.5 & 6.6 & 3.3 & $8.5^{*}$ \\
\hline 11 (3). I have become more religious or spiritual & 3.0 & 3.4 & 4.4 & 0.6 \\
\hline
\end{tabular}

Note. The experiences are ordered from higher to lower frequency in the total sample (the PEAS item number is indicated in parentheses). PEAS $=$ Positive Experiences in Adversity Scale. ${ }^{*} p<.05,{ }^{* * *} \mathrm{p}<.001$.

\section{Discussion}

The present study aimed to examine the psychological impact experienced by the Spanish population associated with the exceptional confinement situation decreed by the Spanish government, in the months of March and April of 2020 and related to the COVID-19 pandemic. More specifically, we wanted to investigate (a) the emotional impact related to possible fears linked to coronavirus, (b) the vulnerability/risk and protective factors that could influence this emotional impact, (c) the negative emotional impact (distress) associated with the psychosocial stress situation of confinement, and (d) a possible positive psychological impact. We also pretended to develop a new evaluation instrument designed to assess the psychological impact of COVID- 19 .

Concerning the first objective, our results indicate that during the confinement period fears of coronavirus are very frequent in participants. The 10 most common fears (indicated in Table 3) mainly concern fears related with infection, disease and death on account of coronavirus. Five of the 10 most common fears belong to this fear category. They are followed by fears related to work and loss of income, and fears of social isolation. Fears of shortness of basic necessities resulted to be less frequent. The prevalence of these fears is very high, as more than $20 \%$ of the population reported having suffered them with high or extreme intensity. Some fears appear to be especially severe as they are felt very intensely by more than $40 \%$ of participants. Among these fears are dread of the death of a close relative, infection of a close relative, spreading of the virus, and isolation from close relatives and close friends.

This pattern is very similar between participants, independent of gender and age. However, and as expected, the prevalence is always higher in women than in men (the differences are significant for all fear types). These data are consistent with the extant literature, and suggest a higher vulnerability of the woman to suffer fears and phobias, generally independently from the fear type concerned (Adams et al., 2012; Sandín, 1997, 2008, 2018). Fears of coronavirus are also more prevalent in lower age participants. The highest percentages were found for the age group from 19 to 30 years, and the lowest for the participants in the highest age group. Nevertheless, contrary to what is reported for gender differences, differences in function of age are not significant for all fear types. Differences are fundamentally found for the 10 most frequent fears (see Table 4).

As far as we know, this is the first publication that examines the specific fears related to coronavirus in population submitted to confinement for COVID-19. An important result is that there are many fear types apparently generated by this special situation of psychosocial stress; we have described 18 relevant fears, and the most prevalent one was experienced by one of every two persons. Another important aspect we highlight is that 
the percentages indicated in Tables 3 and 4 correspond to the frequencies of individuals that experienced each fear with high or extreme intensity, which suggests that they refer to fears of high clinical significance that therefor require some type of psychological intervention.

A second objective of this work consisted in studying the possible role of potential vulnerability/risk and protective factors that may have been implicated in the clinical levels of fears of coronavirus. To this purpose we developed predictive models, applied to the general level of coronavirus fears and to each of the four fear categories. These models were based on multiple regression analyses, and indicate that vulnerability/risk as well as protective factors are implicated in prediction of coronavirus fears. The vulnerability factors consist of 3 dispositional factors that include intolerance of uncertainty, negative affect and gender (belonging to being of female gender increases vulnerability), and 3 factors associated with the confinement context (that is, media exposure, living with chronically ill persons, and living with children less than 12 years old). Of all these vulnerability or risk factors, the variable that demonstrates highest predictive power was intolerance of uncertainty, followed by media exposure. Both variables are significantly implicated in every one of the five predictive models as described (see Table 6). The remaining variables (except living with children less than 12 years old), that is, living with chronically ill persons, negative affect, and being of female gender, significantly participate in four of the five predictive models and thus are highly relevant vulnerability factors. Living with children less than 12 years old only resulted significant for predicting fears related to shortage of basic necessities, and its predictive power is less than that from the model's other independent variables.

We can therefore emphasize the special role of intolerance of uncertainty and media exposure. The influence of intolerance of uncertainty as a vulnerability factor could be understood from its transdiagnostic nature (Sandín, Chorot and Valiente, 2012) with capacity to influence the etiopathogenesis of emotional disorders, and especially anxiety disorders (Pineda, 2018; Rosser, 2019). With respect to the pernicious effect of excessive exposure to information on coronavirus through different media, our data are in line with preliminary evidence published by Gao et al. (2020) and Roy et al. (2020), who clarified its negative influence on anxiety, preoccupation and sleep problems.

The 5 protective factors (age, income level, work outside the home, having a private garden with the home, and positive affect) behave more irregularly and their predictive power is much less than that of the vulnerability or risk factors. Age appears to be a protective factor of fear of social isolation. Income level positively predicts the global score of coronavirus fears and those related to work and income. In the first case, the predictive power is low. In the second case, the power is more relevant and expected as it concerns fears linked to work and income. According to our results, having to work outside the home during confinement is a protective factor for fears related to scarcity of basic necessities and fears related to work and income. Although this association in theory is coherent with what is to be expected given the nature of these two fear types, a positive association could be expected with fears and preoccupations related to fear of infection/disease/death (that is, a positive predictive factor for this type of fears and, thus, acting as risk factor). The fact of having a private garden with the house appears to offer some protection against fears of social isolation and fears related to work and income. Though the effect in the second case could be interpreted on the basis that having a private garden usually implies a higher income level, the predictive model also includes the income level variable and therefor the effect of this last variable was controlled for.

Against what was expected, we did not find significant relationships between levels of fears related to COVID-19 and some sociodemographic variables, such as location of the home (urban or rural), living together with dependent persons, and working in health services or as a member of the security forces. The study of Gao et al. (2020) found that living in urban areas and having certain economic stability acted as protective factors against generalized anxiety syndrome in Chinese population. The protective role of economic level is consistent with our data, but our study does not support the hypothesis that living in an urban area is associated with a lower emotional impact than living in a rural area. Otherwise, we expected to find higher fears levels in participants that lived with dependent persons, but the data do not support this hypothesis. Finally, it could be supposed that participants working in the health sector or related to this field, being more exposed to coronavirus-related situations, would present a higher level of emotional impact through fears related to infection/disease/death, but the obtained results do not support this premise.

The third objective of the present study consisted in examining the negative emotional impact, or distress level, associated with the psychosocial stress situation of confinement. Basically we wanted to examine the emotional profile type related to the impact of coronavirus on 10 negative emotional states (anxiety, depression, preoccupation, loneliness, hopelessness, 
anger/irritability, nervousness, stress, and restlessness) and on sleep. The results we present in Figure 1 suggest a similar profile in the groups of men and of women, where cases prevail of elevated preoccupation, stress, and despair, and a significant decrease in cases of irritability/anger and feelings of loneliness. In the group of women also stands out the percentage of depression cases $(29.7 \%)$. Sleep problems have a prominent percentage in both profiles. Regarding the age groups we find that, although the three groups have a similar pattern, the emotional profile of the younger group (1930 years) presents superior levels. For example, cases of sleep problems are more than double in the group of $19-30$ years $(36.4 \%)$ than in the groups of $31-50(17 \%)$ and more than 51 years (12.2\%). Something similar was found for stress, hopelessness and depression (see Figure 2).

These results are consistent with some of the few data published on the emotional impact associated with coronavirus. The present study found that the principal negative emotional states appear to be significantly more important; the same goes for sleep problems. We found that depression is only somewhat more affected than anxiety, in line with the results of Gao et al. (2020) in Chinese population, although these authors found superior percentages of cases in depression as well as in anxiety, which could be due to the use of a lighter criterion for establishing cut-off points. Our data are also consistent with those published by Roy et al.(2020) and Cao et al. (2020) on anxiety and preoccupation; the results of this last author, nevertheless, were much lower, something that could be explained by the sample from the entire Chinese territory at a point in time when in China the pandemic already had remitted. Sleep problems had already been described in some of these previous studies (Liu et al., 2020; Roy et al., 2020), indicating that sleep could be disturbed to some degree. Concerning the remaining negative emotion experiences examined in our study (stress, nervousness, hopelessness, feelings of loneliness, anger/irritability, and restlessness) we are not aware of other studies that supplied relevant information on possible affectation related to coronavirus.

Regarding the fourth objective we examined the possibility that not all psychological impact generated by coronavirus would be negative. In this respect we found an important percentage of participants indicating to have experimented positive experiences owing to confinement and the situation generated by coronavirus. More than half of the participants informed to have learned to value outdoor activities more. Other positive experiences reported by more than a third of the sample were to have been more interested in other persons
(36.8\%), to have learned to value personal relationships more $(36.6 \%)$, to be more concerned with the future (33.6\%), and to enjoy passing time with the family (31.3\%) (other positive experiences of the participants are indicated in Table 7).

For all types of experiences, except for the experience of having become more religious or spiritual, the percentage was always higher in the group of women than in men. In other words, women were more able than men to «see» (or value) and experience the positive aspects that a seriously adverse situation may give us. We also found an inverse relationship between age and positive experiences; the higher percentage of participants having had these experiences always corresponded to the lower age group (19-30 years). Therefore, more than older people, young persons appear to be more able to perceive and value positive aspects that may emerge in different adversities generated by situations of extreme psychosocial stress.

Finally, one objective of the study was to provide a new instrument for assessing the psychological impact produced by the COVID-19 pandemic situation, to be applied in situations of confinement and other contexts associated with coronavirus. We incorporate the Questionnaire of Psychological Impact of Coronavirus (See Appendix I), which has been partially validated in the present study. The questionnaire focuses on assessing core psychological aspects related to the coronavirus pandemic. It includes independent scales for assessment of coronavirus experience, media exposure, behaviors associated with confinement, use of preventive behaviors, and COVID-19 impact on fears and preoccupations, experiencing negative emotions, symptoms of posttraumatic stress, interference with routine functioning, and also possible positive psychological effects.

\section{General conclusions and implications}

This is the first empirical publication on the psychological impact of the confinement for coronavirus decreed by the government throughout the Spanish territory. It is also the first investigation on the psychological impact associated with a prolonged and generalized period of quarantine owing to coronavirus. With the present study relevant information is provided on the negative impact (emotional impact) and positive impact (positive experiences) associated with coronavirus (or with the COVID-19 disease). Moreover, a new self-report instrument is provided for evaluating the psychological impact (fundamentally the emotional impact) produced by coronavirus. We highlight some conclusions of the study: 
1. Fears of coronavirus are extremely frequent in participants, but notable differences exist between types of fear.

2 . We found four types or categories of fears of coronavirus related to: (1) infection, disease and death, (2) shortness of basic necessities, (3) social isolation, and (4) work and loss of income.

3. Among the 10 most common fears of coronavirus, half pertain to the first category, 3 correspond with fears related to work and loss of income, and 2 are fears of social isolation.

4. Several of the fears of infection, disease and death (e.g. death or infection of a close relative, or spreading of the virus) are found in nearly half the studied population (in more than $40 \%$ ).

5. One of the fears of social isolation, that is, the fear not to be able to see family or friends, is present in more than $40 \%$ of participants.

6.In general, the 10 most common fears are suffered by 1 of every 3 participants.

7. Women are much more vulnerable than men to all types of examined fears: for every man with a coronavirus fear there typically are 2 women with the same fear.

8. Younger people are, more than older people, vulnerable to an important number of fears, especially those related to social isolation and infection/disease/death. For example, fear of the death of a loved one or that a close relative gets infected is produced in $55.9 \%$ and $48.3 \%$ of the younger ones, but in only $30 \%$ and $26.7 \%$ of the older ones (over 50 years).
9. Intolerance of uncertainty, negative affect and being of female gender are factors of fear vulnerability (Table 9).

10. Media exposure, living with chronically ill persons, and living with children less than 12 years old are risk factors.

11. Income level, age, work outside the home, having a private garden with the home, and positive affect are protective factors.

12. Vulnerability and risk factors have a strong predictive power over fears, certainly much stronger than protective factors. Intolerance of uncertainty (among vulnerability factors) and Media exposure (among risk factors) stand out.

13. The emotional profile associated with COVID-19 suggests a prevalence of symptoms of preoccupation, stress (feeling stressed or overwhelmed) and hopelessnes, and sleep problems, with depression in the group of women standing out. We also found elevated impact levels on anxiety, nervousness and restlessness. The profile reflects a minor impact from coronavirus on emotions of anger/irritability and feelings of loneliness.

14. The profile shows a significantly higher impact on all variables in the group of women than in men; it also reflects significant effects owing to age (major impact corresponds to lower age).

15. The present study spotlights that the special situation generated by the COVID-19 pandemic can also produce positive effects. Many participants experimented effects on valuing new aspects of life, knowing or

Table 9. Predictive power of vulnerability/risk and of protective factors for coronavirus fears (based upon results given in Table 6)

\begin{tabular}{|c|c|c|c|c|c|}
\hline & \multicolumn{5}{|c|}{ Type of fear } \\
\hline & InDiDe & ShoBa & SoIso & WorInc & Total fea \\
\hline \multicolumn{6}{|l|}{ Vulnerability/risk factor } \\
\hline Intolerance of uncertainty & ++++ & ++++ & ++ & +++ & ++++ \\
\hline Media exposure & +++ & ++ & +++ & ++ & +++ \\
\hline Being of female gender & +++ & - & + & + & +++ \\
\hline Negative affect & +++ & - & ++ & ++ & +++ \\
\hline Living with chronically ill people & +++ & ++ & - & + & ++ \\
\hline Living with children less than 12 years old & - & + & - & - & - \\
\hline \multicolumn{6}{|l|}{ Protective factors } \\
\hline Income level & - & - & - & +++ & + \\
\hline Working outside of the home & - & ++ & - & ++ & - \\
\hline Private garden with home & - & - & + & + & - \\
\hline Positive affect & + & - & - & - & - \\
\hline Age & - & - & ++ & - & - \\
\hline
\end{tabular}

Note. The sign + indicates a significant predictive effect (the number of + signs was established from the size of the regression coefficient). The sign - denotes lack of significant effect. InDiDe= Fear of infection, disease and death; ShoBa = Shortness of basic necessities); SoIso $=$ Fear of social isolation; WorInc $=$ Fears related to work and income. 
living new positive experiences, learning to value important things they were not aware of before, or discovering new capacities or interests.

16. Finally, it should be underscored that the study provides a new self-report instrument for the assessment of psychological impact associated with the COVID-19 pandemic. The questionnaire includes 9 independent scales: (1) Experience with Coronavirus (ECOVI); (2) Media Exposure (ME); (3) Quarantine Related Behaviors (QRB); (4) Use of Preventive Behaviors (UPB); (5) Fear of Coronavirus Scale (FCS); (6) Distress Scale (DS); (7) Posttraumatic Stress Symptoms Scale (PSSS); (8) Coronavirus Interference Scale (CIS); and (9) Positive Experiences in Adversity Scale (PEAS).

These results have relevant clinical implications. It should be taken into account that the percentages of persons affected by coronavirus fears, as earlier described, correspond with participants that informed having experimented the fear with much or extreme intensity (we did not consider fears assessed with «moderate» intensity). This indicates that those fears have clinical significance and, thus, a considerable number of persons require specialized psychological attention. Something similar could be said as to the emotional symptoms reported by participants, as arises from the emotional symptoms profiles obtained in the study.

The study provides relevant evidence on some factors of vulnerability and risk that can amplify the emotional symptomatology and coronavirus fears. Intolerance of uncertainty and media exposure appear as two first grade vulnerability factors. Other outstanding vulnerability/risk factors are negative affect, living with chronically ill persons and belonging to the female gender. Unfortunately, the protective factors we examined resulted to be of lesser relevance, although some appear to be implicated and should be taken into account. We consider that the evidence obtained in this study can be of great relevance for implementing intervention and prevention programs on the psychological effects related to coronavirus and, especially, to confinement situations we had and may have in the future. The programs may benefit from the results here obtained considering, for example, the possible noxious effects from excessive media exposure (Garfin, Silver y Holman, 2020), or the elaboration of intervention programs (e.g., Espada, Orgilés, Piqueras y Morales, 2020), in which clinically relevant therapeutic objectives and vulnerability/risk or protective variables are integrated with the objective to improve psychological attention to persons affected by the coronavirus-related special psychosocial situation.

Another novel aspect of the present study is that it establishes the coronavirus phenomenon as possibly providing positive psychological influences. In particular, the adverse situation generated by the pandemic could make persons to live positive or nurturing experiences, and make them more aware of or value life aspects they had not noticed before. For example, half the participants informed to have better understood the value of outdoor activities. Many showed more interest in other persons and for interpersonal relationships, or could positively value having passed more time with the family, or being more interested in the future. This type of experiences could be of great value to enhance health and resilience of affected persons, and could occupy an important place in intervention programs.

The limitations of the study include being basically centered on emotional impact, disregarding other possible types of psychological effects. Neither was a relationship established between confinement and possible psychopathological diagnostics beyond the cutoff points, established in the evaluating system of the self-report. To be able to establish such association it is necessary to conduct clinical interviews that are more or less structured, and this requires other types of study design that, without a doubt, should be applied in the future. The sample used consisted mainly of university students of UNED, that is, highly educated participants. Nevertheless, and except for this aspect, UNED students made up a type of sample that is very similar to the general population (in the remaining sociodemographic aspects). Future studies should include other types of samples to investigate other forms of psychological impact, both negative and positive.

\section{Conflicts of interest}

Authors declare no conflicts of interest.

\section{References}

Adams, T. G., Sawchuk, C. N., Cisler, J. M., Lohr, J. M., \& Otalunji, B. O. (2012). Specific phobias. En P. Emmelkamp \& T. Ehring (Eds.). The Wiley handbook of anxiety disorders (vol. 1, pp. 297-320). Chichester, UK: Wiley.

Barrera-Herrera, A., Neira-Cofré, M., Raipán-Gómez, P., Riquelme-Lobos, P., y Escobar, B. (2019). Apoyo social percibido y factores sociodemográficos en relación con los síntomas de ansiedad, depresión y estrés en universitarios chilenos. Revista de Psicopatología y Psicología Clínica, 24, 105-115. https://doi.org/10.5944/rppc.23676.

Boletín Oficial del Estado (BOE) (2020). Real Decreto 463/2020, de 14 de marzo, por el que se declara el estado de alarma para 
la gestión de la situación de crisis sanitaria ocasionada por el COVID-19. https://www.boe.es/eli/es/rd/2020/03/14/463.

Brooks, S. K., Webster, R. K., Smith, L. E., Woodland, L., Wessely, S., Greenberg, N., \& Rubin, G. J. (2020). The psychological impact of quarantine and how to reduce it: Rapid review of the evidence. Lancet, 395, 912-920. https://doi.org/10.1016/ S0140-6736(20)30460-8.

Cao, W., Fang, Z., Hou, G., Han, M., Xu, X., Dong, J., \& Zheng, J. (2020). The psychological impact of the COVID-19 epidemic on college students in China. Psychiatry Research, 112934. https://doi.org/10.1016/j.psychres.2020.112934.

Carleton, R. N., Norton, M. P. J., \& Asmundson, G. J. (2007). Fearing the unknown: A short version of the Intolerance of Uncertainty Scale. Journal of Anxiety Disorders, 21, 105-117. https://doi.org/10.1016/j.janxdis.2006.03.014.

Espada, J. P., Orgilés, M., Piqueras, J. A., y Morales, A. (2020). Las buenas prácticas en la atención psicológica infantojuvenil ante el COVID-19. Clínica y Salud (in press). https:// doi.org/10.5093/clysa2020a14.

Gao, J., Zheng, P., Jia, Y., Chen, H., Mao, Y., Chen, S., ... \& Dai, J. (2020). Mental health problems and social media exposure during COVID-19 outbreak. Plos One, 15, e0231924. https:// doi.org/10.1371/journal.pone.0231924.

Garfin, D. R., Silver, R. C., \& Holman, E. A. (2020). The novel coronavirus (COVID-2019) outbreak: Amplification of public health consequences by media exposure. Health Psychology, 39, 355-357.

Wikipedia (2020a). https://es.wikipedia.org/wiki/Anexo:Cronolog\% C3\%ADa_de_la_pandemia_de_enfermedad_por_ coronavirus_de_2019-2020\#Enero_de_2020.

Wikipedia (2020a). https://es.wikipedia.org/wiki/Pandemia_de_ enfermedad_por_coronavirus_de_2020_en_Espa\%C3\%B1a.

Liu, N., Zhang, F., Wei, C., Jia, Y., Shang, Z., Sun, L., ... \& Liu, W. (2020). Prevalence and predictors of PTSS during COVID-19 outbreak in China hardest-hit areas: Gender differences matter. Psychiatry Research, 112921. doi: https://doi. org/10.1016/j.psychres.2020.112921.

Pineda, D. (2018). Procesos transdiagnóstico asociados a los síntomas de los trastornos de ansiedad y depresivos. Universidad Nacional de Educación a Distancia. Tesis doctoral.

Rosser, B. A. (2019). Intolerance of Uncertainty as a Transdiagnostic Mechanism of Psychological Difficulties: A Systematic Review of Evidence Pertaining to Causality and Temporal Precedence. Cognitive Therapy and Research, 43, 438-463. https://doi. org/10.1007/s10608-018-9964-z.

Roy, D., Tripathy, S., Kar, S. K., Sharma, N., Verma, S. K., \& Kaushal, V. (2020). Study of knowledge, attitude, anxiety \& perceived mental healthcare need in Indian population during COVID-19 pandemic. Asian Journal of Psychiatry, 102083. doi: 10.1016/j.ajp.2020.102083.

Sandín, B. (1997). Ansiedad, miedos y fobias en niños y adolescents. Madrid: Dykinson.

Sandín, B. (2009). El estrés. En A. Belloch, B. Sandín y F. Ramos (Eds.). Manual de psicopatología, Vol. 2 (ed. rev., pp. 3-42). Madrid: McGraw-Hill.

Sandín, B. (Ed.) (2008). Las fobias especificas (ed. rev.). Madrid: Klinik

Sandín, B., y Chorot, P. (2017). Cuestionario de Sucesos Vitales (CSV). Revista de Psicopatología y Psicología Clínica, 22, 95115. https://doi.org/10.5944/rppc.vol.22.num.2.2017.19729.

Sandín, B., Chorot, P., Lostao, L., Joiner, T. E., Santed, M. A., y Valiente, R. M. (1999). Escalas PANAS de afecto positivo y negativo: Validación factorial y convergencia transcultural. Psicothema, 11, 37-51. https://doi.org/10.5944/rppc.vol.12. num.2.2007.4036.

Sandín, B., Chorot, P., y Valiente, R. M. (2012). Transdiagnóstico: Nueva frontera en psicología clínica. Revista de Psicopatología y Psicología Clínica, 17, 185-203. https://doi.org/10.5944/ rppc.vol.17.num.3.2012.11839.

Sandín, B., Chorot, P., y Valiente, R. M. (2018). Trastornos de ansiedad en niños y adolescentes. En J.C. Arango-Lasprilla, I. Romero, N. Hewitt-Ramírez, y W. Rodríguez (Eds.), Trastornos psicológicos y neuropsicológicos en la infancia y la adolescencia (pp. 119-161). Bogotá: Manual Moderno.

Sandín, B., Chorot, P., Valiente, R. M., y Pineda, D. (2012). Versión española de la Intolerance of Uncertainty Scale-12. Universidad Nacional de Educación a Distancia, Madrid.

Wikipedia (2020a). Anexo: Cronología de la pandemia de enfermedad por coronavirus de 2019-2020. https://es. wikipedia.org/wiki/Anexo:Cronolog\%C3\%ADa_de_la_ pandemia_de_enfermedad_por_coronavirus_de_2019-2020.

Wikipedia (2020b). Pandemia de enfermedad por coronavirus de 2020 en España. https://es.wikipedia.org/wiki/Pandemia_de_ enfermedad_por_coronavirus_de_2020_en_Espa \%C3\%B1 


\section{Appendix I. Coronavirus Psychological Impact Questionnaire (CPIQ)}

The Coronavirus Psychological Impact Questionnaire (CPIQ) is an instrument designed to assess several psychological aspects associated with coronavirus, especially emotional impact. It includes several initial sociodemographic questions and 9 independent scales (as independent scales, each one can be applied separately). These scales are described as follows:

(1) Experience with Coronavirus (ECOVI);

(2) Media Exposure (ME);

(3) Quarantine Related Behaviors (QRB);

(4) Use of Preventive Behaviors (UPC);

(5) Fear of Coronavirus Scale (FCS);

(6) Distress Scale (DS);

(7) Posttraumatic Stress Symptoms Scale (PSSS);

(8) Coronavirus Interference Scale (CIS); and

(9) Positive Experiences in Adversity Scale (PEAS)

\section{Initial questions}

Following are some general questions related to the coronavirus quarantine period. Please answer as applicable to you.

1. You presently live in: $\square$ a village $\square$ a city

2. Your home has a private garden? $\square$ Yes $\square$ No

3. Do minors under 12 years live with you? $\square$ Yes $\square$ No

4. Do you live with chronically ill persons (diabetes, cardiovascular disease, etc.)? $\square$ Yes $\square$ No

5. Is any dependent person requiring high attention? $\square$ Yes $\square$ No

6. Have you been working during confinement outside the home as a health worker (in hospital, ambulance, health center, etc.)? $\square$ Yes $\square$ No

7. Have you been working during confinement as a support member for health activities of security forces (police, civil guards, military, etc.)? $\square$ Yes $\square$ No

\section{(1) Experience with Coronavirus (ECOVI)}

Please answer the questions related to coronavirus that follow.

1. Have you been having symptoms that could have been caused by coronavirus? $\square$ Yes $\square$ No

2. Did you have symptoms and was a diagnosis of coronavirus confirmed? $\square$ Yes $\square$ No

3. Were you hospitalized for coronavirus? $\square$ Yes $\square$ No

4. Was any person that lives with you infected with coronavirus? $\square$ Yes $\square$ No

5. Was any close relative or loved one that does not live with infected with coronavirus? $\square$ Yes $\square$ No

6. Was any close relative or loved one hospitalized for coronavirus? $\square$ Yes $\square$ No

7. Did any close relative or loved one die with coronavirus? $\square$ Yes $\square$ No

8. Did any friend or fellow worker die with coronavirus? $\square$ Yes $\square$ No

9. Do you think you can avoid infection with coronavirus if you take the necessary precautions? $\square$ Yes $\square$ No

10. Do you have confidence that our health system can cope with coronavirus? $\square$ Yes $\square$ No

11. Do you think the actual situation generated by coronavirus will be resolved soon? $\square$ Yes $\square$ No

12. Do you rely on the information on coronavirus in the communication media? Do you consider it true and correct? $\square$ Yes $\square$ No

\section{(2) Media Exposure (ME)}

Please indicate the time you spend each day on staying informed about coronavirus 
Little or nothing $=1$

Only at specific moments $=2$

The main part of the day $=3$

1. How much do you watch TV to stay informed about coronavirus?

2. How much time do you use internet (digital news, Google, etc.) to stay informed about coronavirus?

3. How much time do you use social media (WhatsApp, Twitter, etc.) to stay informed about coronavirus?

4. How much time do you dedicate to the written press (on paper) to stay informed about coronavirus?

\section{(3) Quarantine Related Behaviors (QRB)}

Following are indicated several conducts related to the confinement period and to coronavirus. Please answer choosing Yes or No as applicable to you.

1. Have you been leaving your home (your present residence) regularly for labor issues? $\square$ Yes $\square$ No

2. Have you been sleeping more than before? $\square$ Yes $\square$ No

3. Have you been watching more TV than before? $\square$ Yes $\square$ No

4. Have you been working out regularly (3 or more days a week)? $\square$ Yes $\square$ No

5. Have you been using social media more than before (WhatsApp, Instagram, etc.)? $\square$ Yes $\square$ No

6. Have you changed routines much (time of going to bed, getting up, lunch, dinner, etc.)? $\square$ Yes $\square$ No

7. Have you been using the internet more than before? $\square$ Yes $\square$ No

8. Have you been spending more time than before seeing films, read, or play videogames? $\square$ Yes $\square$ No

9. Have you been seizing the opportunity to realize activities at home that before you had no time for? $\square$ Yes $\square$ No

10. Have you been maintaining your self-care (personal cleanliness, clothing, stay groomed)? $\square$ Yes $\square$ No

\section{(4) Use of Preventive Behaviors (UPB)}

These are some of the behaviors to avoid coronavirus infection. Please answer choosing Yes or No as applicable to you.

1. Do you always or nearly always wear a face mask when leaving home? $\square$ Yes $\square$ No

2. Do you always or nearly always wear gloves when leaving home? $\square$ Yes $\square$ No

3. Do you always or nearly always maintain the safety distance to other persons outside (at least 2 meters)? $\square$ Yes $\square$ No

4. Do you think you wash or disinfect your hands with excessive frequency? $\square$ Yes $\square$ No

5. Do you habitually disinfect objects and surfaces with disinfecting gel, bleach, alcohol, etc.? $\square$ Yes $\square$ No

6. Do you habitually take precautions returning from the supermarket, washing food products, disinfecting your mobile phone or the keys, etc.? $\square$ Yes $\square$ No

7. Do you habitually protect yourself from touching possibly infected areas, such as door handles, elevators, credit card readers, etc.?

\section{(5) Fears of Coronavirus Scale (FCS)}

Indicate how much fear and preoccupation you felt during the confinement period when thinking of the following situations related to coronavirus

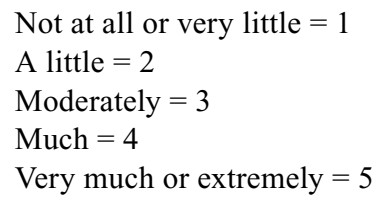

1. That you could become infected with coronavirus

2. That you could die with coronavirus

3. That a relative or loved one could get infected

4. That a relative or loved one could die

5. That coronavirus could continue to spread

6. That you could lose your job or part of your job 
7. That you or your family has to go out of the home (shopping, go to work, etc.)

8. That you could lose income

9. That a relative or loved one lose their work

10. That you could infect a relative or loved one

11. That you could become ill or an existing illness could get worse

12. That food or other first necessity products become scarce

13. That something serious would happen to you (an accident, illness, etc.) and must go to the emergency room

14. That you could be left without important things in the house (food, pharmaceutical products, etc.)

15. Not being able to see family or close friends

16. Not being able to celebrate important occasions (a christening, communion, wedding, etc.)

17. See or hear news or stories about coronavirus

18. Be socially isolated

The FCS includes the following subscales: (1) Fear of infection, disease and death (Items 1, 2, 3, 4, 5, 7, 10, 11, 17); (2) Fear of shortness of basic consumption products (Items 12, 13, 14); (3) Fear of social isolation (Items 15, 16, 18); and (4) Fear related to work and income (Items 6, 8,9).

\section{(6) Distress Scale (DS)}

The following relates several emotional experiences people may have more or less frequently. Please, indicate with what frequency you experienced during confinement each of the following emotional experiences.

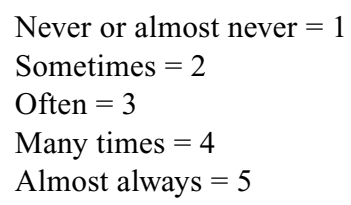

1. Have you been feeling much anxiety or fear?

2. Have you been feeling very sad or depressed?

3. Have you been very preoccupied by many things you could not control?

4. Have you been feeling lonely or isolated?

5. Have you been feeling hopelessness about the future?

6. Have you been feeling irritable, angry, or aggressive?

7. Have you been feeling very nervous?

8. Have you been feeling overwhelmed or stressed?

9. Have you been feeling uneasy or restless?

10. Have you been having sleep problems (did you sleep badly)?

11. Have you been having panic or anxiety attacks?

\section{(7) Escala de Síntomas de Estrés Postraumático (ESEP)}

Related to coronavirus, select with what frequency happened to you during confinement what is indicated hereafter:

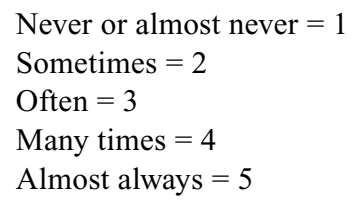

1. Have you been having disturbing and unwanted thoughts or memories about coronavirus?

2. Have you been having nightmares or couldn't you sleep for images about coronavirus?

3. Have these thoughts or memories about coronavirus been making you feel overwhelmed?

4. Have you been trying to avoid these thoughts or bothersome memories over coronavirus?

5. Have the memories over coronavirus been producing physical reactions in you, such as sweating or palpitations?

6. Have any of the disturbing images of coronavirus been invading your mind against your will? 
7. Have these thoughts, memories or images over coronavirus been interfering with your relationships with family or friends?

8. Have these thoughts, memories or images over coronavirus been interfering with your work or your daily activities?

\section{(8) Coronavirus Interference Scale (CIS)}

Did coronavirus or confinement perturb or interfere with your life? Indicate the intensity with which it occurred.

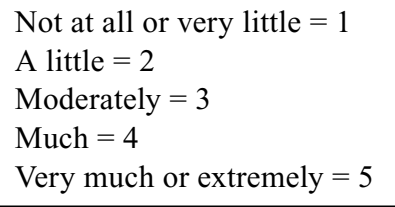

1. Have you been having severe problems at work (being fired, hours reduction, etc.)?

2. Have you been having problems at work (related to displacement, shift changes, workplace tensions, etc.)?

3. Have you been having problems with your studies (problems studying or taking exams)?

4. Have you been having discussions or conflicts with your family?

5. Has it been distressing for you or interfering with your life not being able to see relatives you use to see regularly?

6. Has it been distressing for you or interfering with your life not being able to see your friends?

7. Has it been distressing for you or interfering with your life not being able to carry out activities outside the house (travel, going out)?

8. Have you been having problems doing leisure activities at home (to read, write, see films, video games)?

9. Has it been distressing for you or interfering with your life not being able to carry out physical activities outside the home (sports, physical exercise, go to the countryside)?

10. Has it been distressing for you or interfering with your life not being able to out of the house except for very necessary things?

11. Has it been distressing for you or interfering with your life not being able to have the things you need?

\section{(9) Positive Experiences in Adversities Scale (PEAS)}

At times an adverse situation can make us see or live positive experiences. The confinement situation has many negative aspects, but for some persons can also have positive consequences. Please indicate to what extent it is applicable to you relative to the quarantine period:

Not applicable to me $=1$

Slightly applicable to me $=2$

Somewhat applicable to $\mathrm{me}=3$

Very applicable to me $=4$

Totally applicable to me $=5$

1. I learned to better organize my free time to not get bored.

2. I discovered new hobbies or activities I never realized before and which I like.

3. I have become more religious or spiritual

4. It changed my value scale and now I value and appreciate things I did not value or appreciate before

5. I have been more interested in people important to me, as to their physical and emotional wellbeing

6. I liked spending more time with my family or persons I live with

7. I liked having more free time for me

8. I am more interested in the future than before

9. I learned to appreciate more what we have («you never miss the water till the well runs dry») instead of desiring what we do not have

10. I learned to value personal relationships more

11. I learned to value more the benefits of outdoor activities

12. I enjoyed leisure activities with my family (card games, cooking, etc.) 
